\section{anthropology} \& materialism

\section{Anthropology \& Materialism}

A Journal of Social Research

1 | 2013

Across the Fields

\title{
Eight Thesis on Phantasmagoria
}

Huit thèses sur la fantasmagorie

Ocho tesis sobre la fantasmagoría

\section{Marc Berdet}

\section{(2) OpenEdition}

\section{Journals}

Electronic version

URL: http://journals.openedition.org/am/225

DOI: $10.4000 / a m .225$

ISSN: 2364-0480

Publisher:

CETCOPRA, CRASSH - Center for Research in the Arts Social Sciences and Humanities, Fakultät Gestaltung - Universität der Künste Berlin

\section{Electronic reference}

Marc Berdet, «Eight Thesis on Phantasmagoria », Anthropology \& Materialism [Online], 1 | 2013, Online since 30 October 2014, connection on 01 May 2019. URL : http://journals.openedition.org/am/225 ; DOI : $10.4000 / a m .225$

This text was automatically generated on 1 May 2019.

Tous droits réservés 


\title{
Eight Thesis on Phantasmagoria
}

\author{
Huit thèses sur la fantasmagorie \\ Ocho tesis sobre la fantasmagoría
}

Marc Berdet

\section{AUTHOR'S NOTE}

The first version of these thesis was presented at the "Workshop on Critical Theory", organized the 25-26th August 2010 with the co-operation of the Selbstorganisierte Universität in the RaumErweiterungsHalle, Kreuzberg, Berlin. Thanks a lot to Paula Schwebel, Leena Petersen, Paola Ferruta, Sami Khatib, Johannes Steizinger, Stefano Marchesoni and Jan Rolletschek. And thanks to Christos Lynteris and Jan Sieber for their insightful and witty suggestions. These theses are on construction. All your propositions, comments and critiques (constructive and destructive) are of course very welcomed.

\section{Phantasmagoria is a set of images, more precisely a set of dream-images, i. e. a dreamlike imagery - a fantasy - reified within urban space}

1 1.1. Phantasmagoria is the screen-image which our commodity producing society makes of itself when it refuses to acknowledge that it is essential for it to produce commodities.

2 1.2. Phantasmagoria is "not only" the apparition of human creations "in a theoretical manner, by an ideological transposition". It appears "in the immediacy of their perceptible presence", in an "illumination". It is the result of an ideological process ("ideological transposition"), but it is not perceived as such. It is perceived as pure form.

3 1.3. Like ideology in a larger sense, phantasmagoria is a representation of the imaginary relationship of society to its real conditions of existence. 
4 1.4. As the representation of an imaginary relationship, phantasmagoria is like a dream. Phantasmagoria is a dream that materialises itself in the architecture of the arcades of Paris, in the bourgeois interior under Louis-Philippe, in world exhibitions during the Second Empire, in the Parisian urbanism of Haussmann, in the image of culture and history from humanity's legendary beginnings to its legendary ends, and in the Fremont street of Las Vegas. Phantasmagoria is an image, but this image is concretised (in architecture for example). It also has the concreteness of reality.

5 1.5. Phantasmagoria is inscribed in the ideological process, but in a dreamlike manner, i.e. alongside an hysterical or neurotic process.

6 1.5.1. Phantasmagoria represses one reality from consciousness: the reality of productive forces (process of production and social utility). For example in the World Exhibitions of 1851 and 1867 iron and glass as materials of construction were hidden behind columns and hangings.

7 1.5.2. Phantasmagoria is the repression from consciousness of yet another reality: the reality of exchange value. Example: in bourgeois interior design (in which the collector is the true resident) goods loose their exchange value so as to/ and take on an aesthetic value.

8 1.6. As a traditional image, phantasmagoria reduces the action of the spectator to a contemplative stance. It maintains a sense of the sacred in everyday experience.

9 1.7. As a typically modern rapid succession of images, phantasmagoria gives a feeling of vertigo. Example (paradigmatic): the amusement parks (with their roller coasters, their "twisters", their "caterpillars") at the centre of the World Exhibitions. Phantasmagoria also reduces the action of the spectator to an attitude of pure reaction.

\section{Phantasmagoria is not only an image; it is also the space of immediate experience}

10 2.1. Phantasmagoria is a social space where we move and interact with objects and with one another. It is related to one's experience. It is also an "ambience" where we have social relations and where we enjoy consumption (here we buy "more" than goods).

11 2.2. Phantasmagoria is a space that gives us a frame for immediate enjoyment. Its function is not to repress our capacity for enjoyment, but to stimulate it without mediation. It is the social organisation of the aggregation of our intentions, of our desires.

12 2.3. We do not convert mediated or historical experiences into phantasmagorias, only immediate or "natural" ones.

\section{Phantasmagoria always refers to the inventory of the "History of Civilization", i.e. of an historical or natural "authenticity"}

13 3.1. Phantasmagoria collects one or more kinds of "cultural" or "natural" alibis.

14 3.1.1. Orientalising alibis. Example: the interior space as an oriental boudoir during the orientalist vogue. 
15 3.1.2. Aestheticising alibis. Example: the idealisation of objects in interior space by the bourgeois collector of the 19th century.

16 3.1.3. Naturalising alibis. Example: the plant-like ornaments for modern constructions by Antonio Gaudi.

17 3.1.4. Indexing alibis. Example: the velvet and veiling in the bourgeois interior under Louis Philippe, where it is possible to leave tracks.

18 3.1.5. Historicising alibis. Example: the antique columns for modern constructions in the Pariser Arcades.

19 3.2. Phantasmagorias also merge real worlds, distant countries and fictional worlds without hierarchy.

20 3.2.1. Phantasmagoria entails a horror vacui. It is a dreamlike continuum of these alibis. It accumulates them eclectically and without critique.

21 3.2.2. These alibis can be linked to an ideology of conservation, an archaeological fetishism, an obsession of reproduction (more real than the real) or to an absolute iconicism (the sign of the real being greater than the real).

22 3.2.3. Phantasmagoria inserts into this continuum a symbolic chain that contains, as repressed from consciousness but encrypted in the dreamlike form, the reality of the use value and the reality of the exchange value. It functions like "screen memories".

23 3.3. Pure construction (without alibis) is not a phantasmagoria. Example: pont transbordeur, Marseille.

\section{Phantasmagoria only exists in a society that produces commodities}

24 4.1. Phantasmagoria is historically singular and linked to fetishism, i.e. to the ideological process of inversion in the hypostasis of the commodity-form that appears in Europe in the 19th Century. Although they have the same functions and structure, Greek houses of Roman patricians are not phantasmagorias (we can consider them protophantasmagorias).

4.2. A specific social class, the bourgeoisie, engenders this inversion which generates phantasmagoria. In this way too, phantasmagoria is not general but specific. Phantasmagorias of interior space, of the market, of civilisation (Haussmann's Paris) correspond to different specific sub-classes within the bourgeoisie itself: the trade bourgeoisie; the industrial bourgeoisie; the financial bourgeoisie (supporting Napoleon III).

4.3. The dominant class can also spread its own phantasmagoria to the other classes. Hence phantasmagoria functions as a weapon for the neutralisation of other classes. Example: the phantasmagoria of the market for the workers of the 19th Century. The phantasmagorias of the market suffocated the "workers' parliaments" present to the first World Exhibitions. The dominant class transformed them into a compact mass reducing their action into pure reaction. In the World Exhibitions, individuals were turned into objects subjugated by a divinely revered and poeticised commoditiy (other example: phantasmagoria of brightness spread to the employees of Weimar). 
27 4.4. On the side of the bourgeoisie lays phantasmagoria. But on the opposite side, phantasmagoria can be destroyed. The Paris Commune put a provisory end to phantasmagoria in 1871. The real antithesis to phantasmagoria is not "reality" (economic or social), it is not simply the working class (antithesis to the bourgeoisie) or its culture (antithesis to bourgeois imagination). The real antithesis to phantasmagoria is the open struggle of the oppressed class. It is from this point of view that knowledge becomes possible.

\section{Phantasmagoria pretends to be general (or "dreamlike") although it is specific (or "real")}

5.1. As in ideology, likewise in phantasmagoria a specific class is speaking universally, for all the classes.

5.2. Its historical singularity is real. As a dream, phantasmagoria contains reality (it is like the latent thought of the dream). As stated above it is not metaphysical but related to the economic and social world, to the use value and the exchange value although its form encrypts them.

5.2.1. Phantasmagoria contains the consciousness of one class, the real position and the interest of one class in the battle against other classes. Example: In bourgeois interior space under Louis-Philippe the diagonal position of the carpet revealed the defensive position of the bourgeoisie before feudal and proletarian, old and new social forces.

31 5.2.2. Phantasmagoria also has the function of ideology: the defense of the dominant class.

32 5.3. The universal is oneiric. As a dream, phantasmagoria contains desire (it is what is encrypted into the dream: frustrated or traumatised desire, incomplete happiness). It is not theoretical but sensuous, not symbolic but fantasmatic. Although a specific social class generates it, phantasmagoria is a collective dream shared by more than one class.

5.3.1. Phantasmagoria contains the unconscious of all classes, the desire of the classless society, of reconciliation that we individually know as the oceanic feeling (maybe an expression of the death drive - Fashion: "Madam Death! Madam Death!"). Example: In bourgeois interior space under Louis-Philippe the aesthetic continuum and the loss of the exchange value of the exhibited objects expresses the desire of harmony beyond the society of commodity production and consumption.

5.3.2. As a collective dream, phantasmagoria has the brilliance of utopia (the universal desire of the classless society).

\section{Phantasmagoria is a false synthesis}

6.1. Phantasmagoria is a false synthesis of real and fictional worlds (see 3).

6.2. It is a false synthesis of all social contradictions (there is no more class division in phantasmagoria).

6.3. It is a false synthesis of the past and the present, of the antique and the modern. Example: the arcades made of (modern) iron and glass architecture do not appear as such, but in an "antique" illumination made of column and antique figures. 
6.4. The dialectic image is the real synthesis of the past and the present; a past which is not the antique past or an historical past, but the past that just vanished (das Gewesene, the suffering of the present generation of workers). This recent past is linked to the always-past (das von-jeher-Gewesene, the suffering - or incomplete happiness - of all past generations of workers, indexed on another time-order the classless society or, with Fourier, "harmony", i.e. the place where the primitive vitality of desire can deploy itself without constraint or frustration, where happiness, desire are complete). But this recent past is also linked to the now-of-recognisability (the present place from which historical tensions are frozen and where the possibility of stopping the way things go appears). / pulling the emergency break.

\section{Phantasmagoria is a "historicising" imprisonment (see 3) of utopian forces into a mythic form}

39 7.1. REMINDER 1. Utopia is originally a figurative critique of ideology. It is an imaginary place outside the world where ideology is represented and its social order questioned.

7.1.1. Between Sir Thomas More and Charles Fourier, between the 15th century and the 19th century, utopia was a figurative way of putting into question the passage from the feudal epoch to the industrial world. Merging feudal harmony and machine-dynamics in a fantastic way, the representation of "harmony" by Fourier allowed him to criticise "civilisation".

7.1.2. Consequently, utopia opens up the field of social theory (critical theory of political economy).

7.1.3. Utopia is not originally an idealist concept. The "harmony" of Fourier exists in all of us, in material reality (what is grasped by anthropological materialism), it is only "repressed" by "civilisation". It is what has not happened in its entirety, what was "traumatised". A new social organisation (and not a state of nature) will only go beyond this trauma (this incomplete happiness) and release all these repressed forces (this is also a "theology").

43 7.2. Utopia degenerated. Already in Fourier, the active dynamics of a new harmony became separated from the utopian images of this dynamics. Utopia became autonomous, an "ideal". Utopia in the 20th century is capable of containing critical figures, which can be used by social theory, but it is not sufficient to be a critique in itself.

44 7.3. When utopia degenerates, it becomes a phantasmagoria, i.e. a sort of a figurative ideology realised in the form of myth.

45 7.3.1. REMINDER 2. Myth is a collective storytelling (without author) that explicates definitively the social foundation including its relation to the cosmos. Myth aims to resolve a fundamental social contradiction in a retrieved lost time and its structure is repetition.

46 7.3.2. Phantasmagoria has the structure and the form of myth: repetition and resolution of all social contradictions.

47 7.4. To summarise: Phantasmagoria has the function of ideology (to reproduce the social order), the structure and form of myth (repetition of reconciliation) and the brilliance of utopia (it uses abstractly images of the classless society). 


\section{It is necessary for the social movement to liberate utopia from phantasmagoria}

8.1. It is necessary to liberate the imagery from this mythic structure and form to make a true synthesis of the real world and the possible world, of awakened consciousness and of dream consciousness.

8.2. This operation is possible when phantasmagorical "reality" (architecture, urbanism, etc.) falls into ruin (see the "now of recognisability" above). Example: it is only when the arcades are destroyed (the Arcade of the Opera was destroyed in 1925 to allow the construction of the Boulevard d'Haussmann) that W. Benjamin can save its poetical intensity, its "surrealist" force.

8.3. The operation of re-establishing poetical intensity into human creation (of reconnecting each other) is made from the point of view of the social movement, i.e. the point of view of the struggling and oppressed class linked to its past generations.

\section{Some phantasmagorias}

51 Phantasmagorias of the interior (bourgeois interior, Paris, 1830-1848; Gaudi's Barcelona, 1880-1905); phantasmagorias of the market (World Exhibitions Paris 1855-Shanghai 2010; arcades 1822-1925); phantasmagorias of civilisation (Haussmann's Paris - until the emergence of American cities); phantasmagorias of the eternal return (Nietzsche, Blanqui, Baudelaire); phantasmagoria of happiness (Gründerjahre, 1871-1873); phantasmagoria "of the brightness, of the youthfulness, of culture and personality" (Weimar employees).

\section{Other phantasmagorias}

Disneyland, Coney Island, Las Vegas, Los Angeles (neo-colonialism and the falseness of neo-haciendas, Palace of Living Art, etc.), Dubaï, Xanadu (William Randolf Hearst's castle, as portrayed by Orson Welles), Madonna-Inn in San Luis Obispo, California (with prehistoric rooms, safari rooms, etc.), Paul-Getty museum (reproduction of all great European works of art), gothic Neuschwanstein castle of Ludwig II of Bavaria, Fun Palace (Montreal), "Thames Town", Luodian and Anting New Town (in the suburb of Shanghai), global tourism, new age

\section{Some forerunners}

Greek houses of Roman patricians, cabinet of curiosities in Renaissance Europe, Roman churches with baroque nave, magic lantern, panoramas, dioramas.

\section{Some equivalents}

Taken from the world of fantasy: the fortress of solitude (Superman) 


\section{New phenomena linked to phantasmagoria}

Imagineering, ADHD (attention-deficit hyperactivity disorder)...

\section{ABSTRACTS}

These eight theses condense 8 years of my research on phantasmagoria. They aim to clarify for us today the multiple implications of this concept that Benjamin outlined, but never systematised.

Ces huits thèses condensent huit années de mes recherches sur la fantasmagorie. Elles visent à dégager pour nous aujourd'hui les différentes implications de ce concept dont Walter Benjamin, qui ne l'avait pas systématisé, fut l'inspiration originaire.

Estas ocho tesis, que concentran ocho años de mi investigación sobre la fantasmagoría, tienen la finalidad de traernos hoy en día las diferentes implicaciones de este concepto del cual Walter Benjamin, pese a no sistematizarlo, es la inspiración original.

\section{INDEX}

Mots-clés: imaginaire, idéologie, utopie, théorie urbaine, Benjamin (Walter)

Keywords: imagery, ideology, utopia, urban theory

Palabras claves: imaginario, ideología, teoría urbana, Benjamin Walter

\section{AUTHOR}

\section{MARC BERDET}

Docteur en sociologie à l'Université de la Sorbonne, postdoctorant Marie-Curie (UE) à la faculté de philosophie de l'Université de Potsdam Doctor of Sociology, Paris Sorbonne University, Marie Curie Fellow (EU) at the Faculty of Philosophy, University of Potsdam 